\title{
Microbial Quality and Proximate Composition of Kunu Drinks Produced and Sold in Ikot Ekpene Metropolis, Akwa Ibom State, Nigeria
}

\section{*1EKANEM, JO; ${ }^{2}$ MENSAH, BJ; ${ }^{2}$ MARCUS, NS; ${ }^{2}$ UKPE, BA}

\author{
${ }^{*}$ Department of Microbiology, University of Uyo, PMB 1017, Uyo, Akwa Ibom State, Nigeria. \\ ${ }^{2}$ Department of Science Laboratory Technology, Foundation College of Technology Ikot Idem PMB 1166, Ikot Ekpene, Akwa Ibom State \\ Nigeria. \\ *Corresponding Author Email: johnnykoko01@yahoo.com, Tel.:+2348063011636
}

\begin{abstract}
Kunu is a non-alcoholic Nigerian beverage produced locally from cereals and has been widely accepted as a nutritional drink due to its cost hence, the need for evaluation of its nutritional and safety status. In this study, proximate composition and microbial quality of Kunu drinks sold in Ikot Ekpene metropolis were evaluated. The results show that Kunu consists of $68.5 \%$ moisture, $9.33 \%$ crude protein, $5.5 \%$ crude fat, $3.14 \%$ ash and $49.2 \%$ carbohydrate while the calorie value was $283.67 \mathrm{kcal}$. The Colony counts from theKunu samples ranged from $0.5 \times 10^{5}$ to $3.2 \times 10^{5}$ for total coliform bacteria, $2.5 \times 10^{5}$ to $4.2 \times 10^{5}$ for total heterotrophic bacteria and $5.2 \times 10^{5}$ to $8.0 \times 10^{5}$ for total heterotrophic fungi for the three samples analyzed. Bacterial isolates identification revealed the presence of Bacillus sp, Pseudomonas aeruginosa, Escherichia coli and Streptococcus sp, while the fungal isolates include; Aspergillus flavus, Penicillium $\mathrm{sp}$, Fusarium sp and Saccharomyces cerevisiae. The data revealed that all the Kunu drinks sold within the study area were contaminated and also contained different pathogenic microorganisms which can serve as sources of infections to human. Therefore, proper hygienic and sanitary measures need to be enforced during processing and packaging of this local beverage drink.
\end{abstract}

\section{DOI: https://dx.doi.org/10.4314/jasem.v22i11.1}

Copyright: Copyright (C) 2018 Ekanem et al. This is an open access article distributed under the Creative Commons Attribution License (CCL), which permits unrestricted use, distribution, and reproduction in any medium, provided the original work is properly cited.

Dates: Received: 02 October2018; Revised: 26 October 2018; Accepted 31 October 2018

Keywords: Kunu, Microbial quality, Proximate, Bacteria.

Kunu, a non-alcoholic beverage used to be consumed mainly in the Northern parts of Nigeria is now widely acceptable in almost all parts of Nigeria, owing to its refreshing and nutritive qualities as well as it being cheaper as compared to carbonated drinks (Gaffa et al., 2002; Adejuyitan et al., 2008). Kunu is a popular cereal based non-alcoholic beverage that is prepared from either guinea corn (Sorghum bicolor), millet (Penisetum typhoides), maize (Zea mays), rice (Oryza sativa) or wheat (Triticum aestivum). Traditionally, the production involves steeping of the whole grains for 6-24 hours, wet milling with spices and sweet potato, gelling of about three-quarter of the mixture in hot water, pitching with about one- quarter fresh (ungelled) part of the mixture and then allowing to ferment overnight and the supernatant is ready for consumption (Adejuyitan et al., 2008; Elmahmood, 2007 and Oranusi, 2003).It is also very nutritious and of medicinal value. Kunu has been reported to be high in demand and rich in vitamins, minerals, carbohydrates and proteins (Essien et al., 2009; Adebayo et al., 2010; Folasade and Oyenike, 2012; Oluwajoba et al., 2013).In spite of the benefits derived from this drink (kunu), there have been reports of microbial contamination which may cause spoilage.
Some of the microorganisms implicated in the spoilage of kunu include lactic acid bacteria (LAB) such as Lactobacillus spp., Streptococcus spp. and Leuconostoc spp as well as other food-borne microbial pathogens such as Escherichia coli, Staphylococcus aureus, Bacillus cereus and Salmonella spp. among others (Bibek, 2001; Amusa et al., 2005). Poor hygiene and preparation practices in which the production process is subjected can also introduce microbial pathogens in foods and have been implicated in causing food-borne illnesses (Amusa and Odunbaku, 2009). In developing countries like Nigeria, it has not been possible to have safety control over the processing of hawked foods, because most of the vendors lack the adequate knowledge of food processing and handling practices as well as lack of portable water, proper storage and waste disposal facilities at preparation and service points have resulted in poor unsanitary conditions and thus served as potential microbial contaminants and increased risk to public health (Omemu and Aderoju, 2008; Sperber, 2003).Though there are a lot of literatures on the microbiological and nutritive quality of kunu drinks, there is scarce or no information on the safety and nutritional status of kunu drinks sold in Ikot Ekpene 
where this study was carried out. Hence, the study intends to evaluate the proximate composition and microbial quality of kunu drinks sold in Ikot Ekpene Metropolis as this will serve as a comparative indices as to what is obtainable in other parts of the country and help take holistic and enduring decision towards the production of this food drink.

\section{MATERIALS AND METHODS}

Study Location: Ikot Ekpene is a city in Akwa Ibom State, South-South, Nigeria. Its area is approximately $125 \mathrm{~km} 2$. The city's population is about 254,806 . It is situated at $5.18^{\circ}$ North latitude, $7.71^{\circ}$ East longitude and 159 meters elevation above the sea level.

Sample Collection: Samples of freshly prepared Kunu were collected from different hawkers from 3 different locations (Ator market, Whites market and Oil market) within Ikot Ekpene metropolis. The samples were labeled P, Q and R for Ator market, Whites market and Oil market respectively for ease of identification. They were transferred within an hour of collection to the laboratory in their original package and the contents aseptically withdrawn from the bottles for isolation, enumeration and identification of microorganisms. The remaining samples were used for proximate analysis.

Preparation of Media: The three media (Nutrient Agar, NA; MacConkey agar, MAC; Potato Dextrose Agar, PDA) used were prepared according to the manufactures' procedures (Titan Biotech Ltd. BHIWADI-301019, Rajasthan, India).

Preparation of Nutrient Agar (NA):Twenty eight grams $(28.0 \mathrm{~g})$ of nutrient agar powder was dissolved in $1000 \mathrm{ml}$ of distilled water. The medium was gently heated to dissolve and completely sterilize by autoclaving at $15 \mathrm{psi}\left(121^{\circ} \mathrm{C}\right)$ for 15 minutes. The autoclaved media was allowed to cool before pouring $15 \mathrm{ml}$ each onto sterile Petri dishes and allowed to gel.

Preparation of MacConkey agar (MAC) Agar: This was done by suspending 47 grams of the powder in $1000 \mathrm{ml}$ of distilled water. The suspended was mixed very well and heated with frequent agitation to dissolve the powder completely. The suspended media was sterilized by autoclaving at $121^{\circ} \mathrm{C}$ and $15 \mathrm{psi}$, for 15 minutes. The autoclaved media was allowed to cool before pouring $15 \mathrm{ml}$ each onto sterile Petri dishes and allowed to gel.

Preparation of Potato Dextrose Agar (PDA):This was done by suspending $39 \mathrm{~g}$ of the media in $1000 \mathrm{ml}$ of distilled water. The suspended was mixed very well and heated with frequent agitation to dissolve the powder completely. The suspended media was sterilized by autoclaving at $121^{\circ} \mathrm{C}$ and $15 \mathrm{psi}$, for 15 minutes. The autoclaved media was allowed to cool before pouring $15 \mathrm{ml}$ each onto sterile Petri dishes and allowed to gel.

Microbiological Analysis: One milliliter of each sampled kunu drink was put in $9 \mathrm{ml}$ of sterile distilled water in sterile test tubes, shaken and then serially diluted. From the appropriate dilution, $0.1 \mathrm{ml}$ was inoculated separately on to MacConkey agar, Nutrient Agar and Potato Dextrose Agar plates and spread evenly using sterile bent glass rod. Each experiment was carried out in duplicates to get a mean standard value of the colony forming units $(\mathrm{cfu} / \mathrm{ml})$ on the plates. The inoculated MacConkey agar, Nutrient agar and Potato Dextrose agar plates were incubated at $30^{\circ} \mathrm{C}$ and $35^{\circ} \mathrm{C}$ for 24 and 48 hours respectively. After the period of incubation, the colonies on the plates were counted and recorded as colony forming unit per milliliter $(\mathrm{cfu} / \mathrm{ml})$ and coliform respectively (Harrigan and McCance, 1976). Each of the bacterial colonies on the agar plates was sub-cultured and the pure culture obtained. Isolates were identified by carrying out tests which include Gram staining, spore staining and biochemical tests such as catalase, coagulase, oxidase, citrate utilization, indole, methyl red, urease, VogesProskauer and sugar fermentation (Onyeagba, 2004; Cheesbrough, 2006).

The bacteria isolates were characterized using microscopic techniques and biochemical tests. The identities of the isolates were determined by comparing their characteristics with those of known taxa as described by Bergey's manual of Determinative Bacteriology (Holt et al., 1994) and Cheesbrough, (2006). The cultures used for biochemical test were between 18 to 24 hours old.

Fungal identification and enumeration was based on their colony elevation, colour, texture, shape and arrangement of conidia (spherical or elliptical, unicellular or multicellular), branched or unbranched mycelia, presence or absence of cross walls (whether septate or non-septate) and others. They were enumerated by reference to illustrated manual on identification of some seed borne fungi (Kulwant et al., 1991) and illustrated genera of imperfect fungi (Barnet and Hunter1972).

Proximate Analysis of Kunu Samples: Moisture Determination: Ten $\mathrm{ml}$ of sample was measured in a clean crucible using sensitive balance. The crucible with the sample was placed in an air-dry oven at $105^{\circ} \mathrm{C}$ and left to stay overnight. Then crucible was transferred to oven again and weighted after 2 hours, 
this was repeated until constant weight was obtained. The moisture content (MC) may be calculated as follows:

$$
\operatorname{MC}(\%)=\frac{\left(W_{2}-W_{1}\right)-\left(W_{3}-W_{1}\right)}{\left(W_{2}-W_{1}\right)} \times 100
$$

Where; $\mathrm{W}_{1}=$ weight of empty crucible; $\mathrm{W}_{2}=$ weight of crucible + sample; $\mathrm{W}_{3}=$ weight of crucible +dry sample

Determination of Total Ash: The ash content was determined from the loss in weight that occurred during incineration of the evaporated sample at a temperature high enough to allow all organic matter to be burnt off without allowing appreciable decomposition of the ash constituents. Ashing was carried out in a muffle furnace subjected to heat at $550^{\circ} \mathrm{C}$ for $6 \mathrm{~h}$ (AOAC, 2005).

Determination of Fat: This was carried out using the method of AOAC (2005). Clean and dried thimble were weighed $\left(\mathrm{W}_{1}\right)$ and $5 \mathrm{~g}$ oven dried sample will be added and re-weighed $\left(\mathrm{W}_{2}\right)$. Round bottom flask was filled with petroleum ether $\left(40-60^{\circ} \mathrm{C}\right)$ up to $3 / 4$ of the flask. Soxhlet extractor was fixed with a reflux condenser to adjust the heat source so that the solvent boiled gently, the sample was put in the thimble and inserted into the soxhlet apparatus and extraction under reflux was carried out with petroleum ether for $6 \mathrm{~h}$. After the barrel of the extractor will be emptied, the condenser was removed and the thimble removed, taken into the oven at $100^{\circ} \mathrm{C}$ for $1 \mathrm{~h}$ and later cooled in the desiccator and weighed again $\left(\mathrm{W}_{3}\right)$.

$$
\text { Fat }(\%)=\frac{\mathrm{W}_{2}-\mathrm{W}_{3}}{\mathrm{~W}_{2}-\mathrm{W}_{1}} \times 100
$$

Estimation of Crude fibre: About $2 \mathrm{~g}$ of the sample was defatted with petroleum ether for 2 hours. It was then boiled under reflux for some minutes with $200 \mathrm{ml}$ of a solution containing $1.25 \mathrm{~g}$ of $\mathrm{H}_{2} \mathrm{SO}_{4}$ per $100 \mathrm{ml}$ solution. The solution was filtered through a cloth on fluted funnel and washed with boiling water until they were no longer acidic. The residue was transferred to a beaker and boiled for another 30 minutes with $200 \mathrm{ml}$ of a solution containing $1.25 \mathrm{~g}$ of $\mathrm{NaOH}$ per $100 \mathrm{ml}$. The final residue was then filtered and washed with boiling water several times until it was no longer basic. The residue was finally washed twice with methanol and quantitatively transferred into a pre-weighed crucible and dried at $105^{\circ} \mathrm{C}(1 \mathrm{a})$. The furnace was incinerated at $550 \mathrm{oc}$ and was allowed to stand at this temperature for 2 hours. It was then cooled in a dessicator and weighed as $1_{\mathrm{o}}(\mathrm{AOAC}, 2005)$. The crude fibre is calculated as

$$
\mathrm{CF}(\%)=\frac{1_{\mathrm{a}}-1_{\mathrm{o}}}{\text { Weight of sample taken }} \times 100
$$

Where; $1_{\mathrm{a}}=$ weight of empty crucible; $1_{\mathrm{o}}=$ weight of crucible and its content after incineration

Determination of crude protein: One gram of the sample was introduced into micro Kjeldahl digestion flask and one tablet of Selenium catalyst was added. The mixture was digested on an electro thermal heater until a clear solution was obtained. The flask was allowed to cool after which the solution was diluted with distilled water to 50 and 5 of this was transferred into the distillation apparatus, 5 of $2 \%$ boric acid was added into a 100 capacity conical flask (the receiver flask) and four drops of methyl red indicator were added. A $50 \%$ of $\mathrm{NaOH}$ was continually added to the digested sample until the solution turned cloudy which indicated that the solution had become alkaline. Distillation was carried out in the boric acid solution in the receiver flask with the delivery tube below the acid level. As the distillation was going on, the pink colour solution of the receiver flask turned blue indicating the presence of ammonia. Distillation was continued until the content of the flask was about 50 after which the delivery of the condenser was rinsed with distilled water. The resulting solution in the conical flask was then titrated with $0.1 \mathrm{M} \mathrm{HCl}$ and the protein content calculated (Pearson, 1970; AOAC., 2005).

Determination of Carbohydrate: This was determined as the difference obtained after subtracting total organic nitrogen (protein), Lipid, Ash, Moisture and Fibre from the total dry matter (AOAC., 2005).

Calculation:Carbohydrate $\%=100-$ value of moisture, protein, lipid, ash and fibre

i.e $\mathrm{CHO}=(\mathrm{M}+\mathrm{P}+\mathrm{L}+\mathrm{A}+\mathrm{F})$

Determination of Caloric Value (Energy Level): The caloric value was obtained by multiplying the value of the crude protein, lipid and carbohydrate by 4:9:4 kcal respectively and taking the sum of the product.

\section{RESULTS AND DISCUSSION}

Parameters obtained for the proximate analysis are presented in Table 1 . The $\mathrm{pH}$ was 4.3 which indicate an acidic $\mathrm{pH}$. These values are within the range of 3.80 and 3.99 reported by Innocent et al. (2011), 2.42 to 3.83 recorded by Otaru et al. (2013), 5.25 to 5.65 reported by Amusa and Ashaye, (2009). The acidity of the kunu drinks may be due to the presence of some bacteria which help in acid fermentation of the kunu products. 
Moisture content was $685 \%$. The percentage ash content was 3.14. These values were higher than $0.2 \%$ obtained by Otaru et al. (2013), but the results however agree with 2.00 to $3.00 \%$ obtained by Innocent et al. (2011). The percentage content of crude fat, crude fibre, crude protein and carbohydrate were 5.5, 1.0, 9.3 and 49.20 respectively. Essien et al. (2011) reported that loss of protein during the processing of the drinks may be responsible for the low protein content observed.

\begin{tabular}{ll} 
Table 1: Proximate Composition of Kunu Sample \\
\cline { 2 - 2 } Parameter (\%) & Kunu \\
\hline $\mathrm{pH}$ & 4.3 \\
Moisture content & 68.50 \\
Ash content & 3.141 \\
Crude fat content & 5.505 \\
Crude fibre content & 1.001 \\
Crude protein & 9.333 \\
Carbohydrate & 49.200 \\
Calorie value (kcal) & 283.677 \\
\hline
\end{tabular}

Hamad and Fields (1979) opined that high value of protein content in cereals is often found in the germ and testa which are often sifted off during the preparation of kunu product. The results of the protein content analysis in this work were found to be higher than the values recorded by Essien et al. (2011). The calorie level was $283.6 \mathrm{kcal}$ which reveals that the kunu sample analyzed was rich in carbohydrate and energy.Colony counts of bacteria isolated from fresh kunu samples are presented (Table 2). The counts ranged from $0.5 \times 10^{5}$ to $3.2 \times 10^{5}$ for total coliform bacteria, $2.5 \times 10^{5}$ to $4.2 \times 10^{5}$ for total heterotrophic bacteria and $5.2 \times 10^{5}$ to $8.0 \times 10^{5}$ for total heterotrophic fungi. The results indicate that fresh kunu presented a high bacteria count after $24 \mathrm{hr}$ of incubation. Efiuwevwere and Akoma, (1995) also reported similar abnormality of high bacterial populations in kunuzaki prepared and sold in Jos metropolis (Hatchers et al., 1992). The high colony count is an indication of spoilage as a consequence of either poor hygiene or poor quality of cereals and the water used. Ten microbial isolates including six species of bacteria and four species of fungi were isolated and identified from the kunu samples. The bacterial isolates include; Lactobacillus sp., Staphylococcus sp., Streptococcus sp., Salmonella sp., Escherichia coli and Pseudomonas sp (Table 3) while the fungal isolates were the species of Fusarium, Aspergillus, Penicillium and Saccharomyces sp (Table 4).

Table 2: Total Microbial Count of Kunu Drinks Sold at Ikot Ekpene Metropolis at Three Different Locations

\begin{tabular}{llll}
\hline Locations & Kunu & & \\
\cline { 2 - 4 } & MAC $(\mathrm{cfu} / \mathrm{ml})$ & $\mathrm{NA}(\mathrm{cfu} / \mathrm{ml})$ & PDA $(\mathrm{cfu} / \mathrm{ml})$ \\
Location P & $2.3 \times 10^{5}$ & $2.5 \times 10^{5}$ & $5.2 \times 10^{5}$ \\
Location Q & $0.5 \times 10^{5}$ & $4.2 \times 10^{5}$ & $8.0 \times 10^{5}$ \\
Location R & $3.2 \times 10^{5}$ & $3.7 \times 10^{5}$ & $5.3 \times 10^{5}$ \\
\hline
\end{tabular}

Where; MAC = MacConkey Agar, NA= Nutrient Agar, PDA= Potato Dextrose Agar; Cfu/ml = Colony forming unit per millimeters

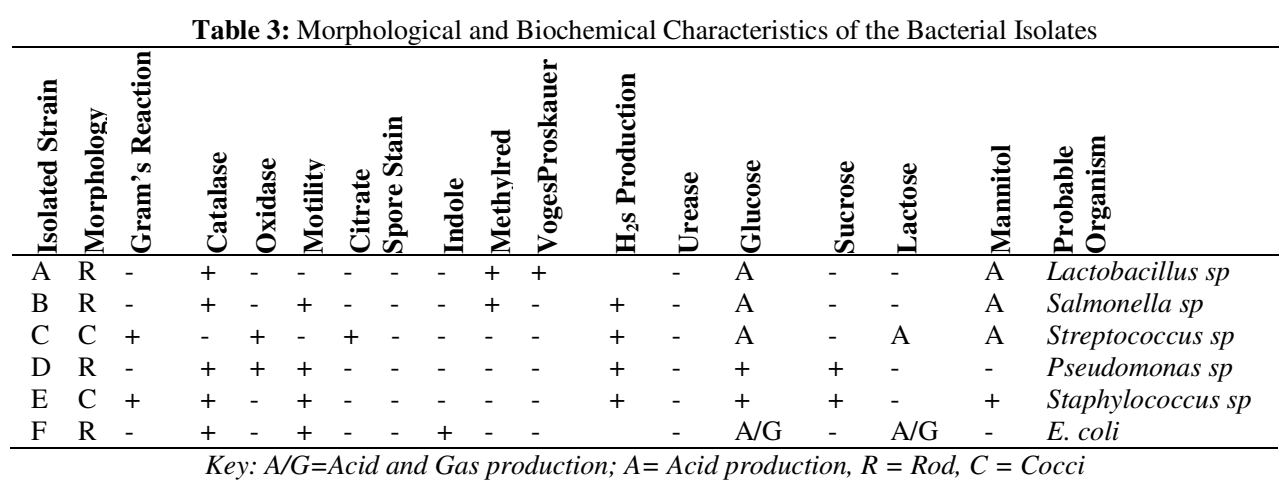

All the Kunu samples were acidic in nature with $\mathrm{pH}$ range of 3.20 to 4.85 . Various researchers have attributed this to the presence of fermentative microorganisms in kunu which causes spoilage of the beverage by fermentation of its carbohydrate content and producing undesirable changes in them, altering their aroma and taste thus making them unpalatable for human consumption. Osuntogun and Abiola (2004) isolated lactic acid bacteria such as Lactobacilli, Leuconostoc and Streptococcus which were reported to possess the ability to ferment carbohydrates to produce lactic acid thus lowering the $\mathrm{pH}$. Lactobacilli have also been isolated from other indigenous nonalcoholic beverages. Olasupo et al. (2002) reported the isolation of Bacillus subtilis, Escherichia coli, Staphylococcus aureus, Klebsiellasp. and Enterococcus faecalis from kunu drink. Akinrele et al. (1980) reported that the yeasts Saccharomyces cerevisiae, Candida mycoderma and molds Cephalosporium, Fusarium, Aspergillus and Penicillium are the major organisms responsible for the fermentation and nutritional improvement of 
cereal based fermented foods (ogi and kunun-zaki). These organisms can cause the spoilage of the beverage if not eliminated during the heating process. The high bacterial and fungal loads in all the Kunu samples can be attributed to the poor hygienic practices of the handlers and possible contamination from utensils and water used for processing the beverage as well as packages used in its distribution.
The bacterial isolates with their frequency and percentage occurrences in each sample is as presented (Table 5). The result showed that Escherichia coli, Staphylococcus sp and Salmonella sp had a hundred percent frequency in all the three samples analyzed .the percentage occurrence in each of the samples are; Sample A (67.0\%), Sample B (100\%) and Sample C $(50 \%)$.

Table 4: Morphological and Cultural Characteristics of Fungi Isolates

\begin{tabular}{|c|c|c|c|c|}
\hline ISOLATES & $\begin{array}{l}\text { CULTURAL } \\
\text { CHARACTERISTICS }\end{array}$ & $\begin{array}{l}\text { MORPHOLOGJCAL } \\
\text { FEATURES }\end{array}$ & MICROSCOPY & IDENTITY \\
\hline F1 & $\begin{array}{l}\text { Yellowish-green } \\
\text { mycelium }\end{array}$ & $\begin{array}{l}\text { Conidia in long chains, } \\
\text { branched cells }\end{array}$ & $\begin{array}{l}\text { Branched smooth } \\
\text { conidiophores, brush-like } \\
\text { conidia head }\end{array}$ & Penicillium $\mathrm{sp}$ \\
\hline $\mathrm{F} 2$ & $\begin{array}{l}\text { Wooly white, black } \\
\text { domains }\end{array}$ & Conidia in chains & $\begin{array}{l}\text { Non-septate hyphae with } \\
\text { many branches }\end{array}$ & Aspergillus sp \\
\hline F3 & $\begin{array}{l}\text { White cottony } \\
\text { With felty colony }\end{array}$ & $\begin{array}{l}\text { Macro-conidia in with } \\
\text { light periphery in chains. }\end{array}$ & $\begin{array}{l}\text { Septate hyphae with } \\
\text { branched conidiophhore }\end{array}$ & Fusarium sp \\
\hline F4 & Colourless & Nil & Egg shaped & Saccharomyces sp \\
\hline
\end{tabular}

Table 5: Percentage Occurrence of the Isolates in each Sample

\begin{tabular}{|c|c|c|c|c|c|c|c|}
\hline Sample & E. coli & Staph. & Pseud. & Salm & Lact & Strept. & Total $(\%)$ \\
\hline $\mathrm{P}$ & + & + & - & + & + & - & 67.0 \\
\hline Q & + & + & + & + & + & + & 100.0 \\
\hline $\mathrm{R}$ & + & + & - & + & - & - & 50.0 \\
\hline
\end{tabular}

Key: E. coli = Escherichia coli, Staph $. \mathrm{sp}=$ Staphylococcus specie; Pseu $. \mathrm{sp}=$ Pseudomonas specie, Lact. $\mathrm{sp}=$ Lactobacillus specie

Conclusion: Proximate analysis of the kunu samples revealed moderate acidity in $\mathrm{pH}$ for the entire sample tested. The result suggests that they are of good nutritive value and could serve as source of protein and energy to. The microbial content of these hawked kunu drinks was high and were contaminated with microorganisms which are potentially pathogenic to man. The presence of these isolated organisms in kunu samples analyzed could serve as an indicator for the need to promote awareness about possible health hazards that could arise due to handling and processing. Hence regulatory agencies should intervene by setting standards in acquisition of raw material, production techniques as well as health status of personnel involved in the production process.

\section{REFERENCES}

Adejuyitan, JA; Adelakun, OE; Olaniyan, SA; Popoola FI (2008). Evaluating the quality characteristics of kunu produced by dry millet sorghum. Afr. J. Biotechnol. 7(13):2244-2247.

Akinrele, I.A., Adeyinka, O; Edwards, CA (1980). The development and production of soy-ogi, a corn based complete protein food. FIIRO Res. Report No. 42.

Amusa, NA;Ashaye, OA (2009). Effects of processing on nutritional, microbiological and sensory properties of kunu-zaki (A sorghum based non- alcoholic beverage) widely consumed in Nigeria. Par. J. Nutr. 8(3):288-292.

Amusa, NA; Odunbaku, OA (2009). Microbiological and Nutritional Quality of Hawked Kunun (A Sorghum Based Non-Alcoholic Beverage) Widely Consumed in Nigeria. Pakistan Journal of Nutrition 8 (1): 20-25

Amusa, NA; Ashaye, OA; Aiyegbayo, AA; Oladapo, MO; Oni, MO; Afolabi, OO (2005). Microbiological and nutritional quality of hawked sorrel drinks (Soborodo) (the Nigerian locally brewed soft drinks) widely consumed and notable drinks in Nigeria. Int. J. Food Agric. Environ. 3: 47-50.

AOAC. (2005). Official Methods of Analysis of AOAC International. 18th Edn., AOAC International, Gaithersburg, MD., USA., ISBN13: 978-0935584752.

Barnet, HL; Hunter, BB (1972). Illustrated Genera of Imperfect Fungi. 3rd Edn., Burges Publishing Company, Minneapolis, pp: 331.

Bibek, R (2001). Fundamental Food Microbiology, 2nd Edition. The CRC Press 1td, Washington DC. 56-90. 
Cheesbrough, M (2006). District Laboratory Practice in Tropical Countries, Part 2. Cambridge University Press, pp.52-70.

Efiucwere, BJO; Akoma, O (1995): The Microbiology of Kunu- Zaki a cereal Beverage from northern Nigeria during the fermentation (production) process. J. Microbial. Biotechnol. 11:491-493.

Elmahmood, AM; Doughari, JH (2007). Microbial Quality Assessment of Kunu- zaki Beverages Sold in Griei Town of Adamawa State, Nigeria. Afr. J. Food Sci. 011-015.

Essien, E;Monago, C;Edor, EA (2011) Evaluation of the nutritional and microbiological quality of Kunun (a cereal based non-alcoholic beverage) in Rivers State, Nigeria. The Internet Journal of Nutrition and Wellness 10: 1-10.

Gaffa, T; Jideani, IA; Nkama, I (2002). Nutrient and sensory qualities of kunun-zaki from different saccharifying agents. Inter. J. Food Sci. Nutrition 53: $109-115$.

Hamad, AM; Fields, MLC (1979). Evaluation of protein quality and available lysine of germinated and fermented cereals. J. Food Sci. 44:456.

Harrigan, WF; McCance, ME (1976). Laboratory methods in food and dairy microbiology. Academic Press Ind. Ltd, London, pp: 25-29, 157, 285-303.

Holt, JG; Kreig, NR; Sneath, PHA; Stanley, JT; William ST (1994). Bergey's manual of Determinative Bacteriology. Baltimore, USA: William and Wikins 213pp.

Innocent, OO; Mariam, YO; Blessed, K; James, TW (2011). Microbial evaluation and proximate composition of kunuzaki, an indigenous fermented food drink consumed predominantly in Northern Nigeria. Internet J. Food Safety, 13:9397.

Kulwant, SJC (1991). An illustrated manual on identification of some Seed borne Aspergilli, Fusaria, Penicillia and their Mycotoxins. Hellerup, Denmark. Danish Government Institute of Seed Pathology for Developing Countries and Department of Biotechnology, The technical university of Denmark.
Mbachu, AE; Etok, CA; Agu, KC; Okafor, OI; Awah, NS; Chidi-Onuorah, LC; Ekwueme, VC; Okpala, J; Ogbue, MO; Ikele, MO (2014). Microbial Quality of Kunu Drink Sold in Calabar, Cross River State, Nigeria. J. Global Biosci. 3(2): 511515

Olasupo, NA; Smith, SI; Akinside, KA (2002). Examination of the microbial status of selected indigenous fermented foods in Nigeria. J. Food Safety. 22 (2): 85.

Omemu, AM; Aderoju, ST (2008). Food safety knowledge and practices of street food vendors in the city of Abeokuta, Nigeria. Food Control. 19:396-402.

Onyeagba, A (2004). Laboratory guide for microbiology. Crystal Publishers, Owerri, Imo State;

Oranusi, SU; Umoh, VJ; Kwaga, JKP (2003). Hazards and Critical Control Points of Kunun-zaki, a NonAlcoholic Beverage in Northern Nigeria. Food Microbiology; 20:127-132.

Osuntogu, B; Aboaba, OO (2004). Microbiological and physicochemical evaluation of some nonalcoholic beverages. Pakistan J. Nutrition, 3:188192.

Otaru, AJ; Ameh, CU; Okafor, JO; Odigure, JO; Abdulkareem, AS (2013). Development, carbonation and characterization of local millet beverage (Kunu). Inter. J. Computational Engineer. Res. 3(4):80-86.

Pearson, D (1970). The Chemical Analysis of Foods. 6th Edn., Churchill Livingstone Publ., London, UK., ISBN-13: 978-0700014576, p. 604.

Sperber, WH (2003). Food safety-future challenges. Food Contr. 14:73-74. 